\title{
Agromyces marinus sp. nov., a novel actinobacterium isolated from sea sediment
}

\author{
Moriyuki Hamada, Chiyo Shibata, Tomohiko Tamura and Ken-ichiro Suzuki
}

Two novel Gram-stain-positive actinobacteria, designated $\mathrm{H} 23-8^{\top}$ and $\mathrm{H} 23-19$, were isolated from a sea sediment sample and their taxonomic positions were investigated by a polyphasic approach. Phylogenetic analysis based on 16S rRNA gene sequence comparisons showed that these isolates were closely related to the members of the genus Agromyces, with similarity range of 94.5-97.4\%. Strains H23-8 and H23-19 contained L-2,4-diaminobutyric acid, D-alanine, D-glutamic acid and glycine in their peptidoglycan. The predominant menaquinones were MK-13 and MK-12, and the major fatty acids were anteiso- $\mathrm{C}_{15: 0}$, anteiso$\mathrm{C}_{17: 0}$ and iso- $\mathrm{C}_{16: 0}$. The DNA G $+\mathrm{C}$ content was $72.3-72.5 \mathrm{~mol} \%$. The chemotaxonomic characteristics of the isolates matched those described for members of the genus Agromyces. The results of phylogenetic analysis and DNA-DNA hybridization, along with differences in phenotypic characteristics between strains $\mathrm{H} 23-8^{\top}$ and $\mathrm{H} 23-19$ and the species of the genus Agromyces with validly published names, indicated that the two isolates should be assigned to a novel species of the genus Agromyces,

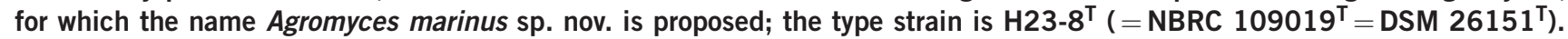
The Journal of Antibiotics (2014) 67, 703-706; doi:10.1038/ja.2014.60; published online 14 May 2014

\section{INTRODUCTION}

The genus Agromyces was proposed by Gledhill and Casida ${ }^{1}$ with Agromyces ramosus as the type species and its description was later emended by Zgurskaya et al. ${ }^{2}$ This genus comprises Gramstain-positive, non-motile, non-spore-forming, filamentous or nonfilamentous, microaerophilic to aerobic actinobacteria. ${ }^{3}$ The members of the genus have 2,4-diaminobutyric acid $\left(\mathrm{A}_{2} \mathrm{bu}\right)$ in their peptidoglycan as the diagnostic diamino acid and MK-12 as the predominant menaquinone with smaller amounts of MK-11 and/or MK-13. Major fatty acids are anteiso- $\mathrm{C}_{15: 0}$, anteiso- $\mathrm{C}_{17: 0}$ and iso$\mathrm{C}_{16: 0}$. The genus Agromyces currently contains 27 recognized species that usually occur in soils. In terrestrial environments, it is suggested that members of the genus play an important role in an interaction with plants. ${ }^{4-6}$ Meanwhile, there are few reports concerning the isolation of Agromyces strains from marine environments $^{7,8}$ and their diversity and role in marine environments remain poorly understood.

The discovery of novel actinobacteria from natural environments is important because it contributes toward understanding not only the diversity of actinobacteria but also their potentials as biological resources for industrial applications. Especially, marine environments attract attention as an isolation source and, in fact, it has been reported that marine-derived microorganisms including actinobacteria are useful for screening of novel bioactive substances. ${ }^{9,10}$ During the course of a study of bacterial diversity in marine environments, two novel actinobacteria were isolated from a sea sediment sample collected in Japan. Comparative 16S rRNA gene sequence analysis revealed that the isolates are phylogenetically related to members of the genus Agromyces. The objective of this study was to determine the taxonomic positions of the isolates by using a polyphasic approach.

\section{MATERIALS AND METHODS}

Bacterial strains and isolation

Two actinobacteria, strains $\mathrm{H} 23-8^{\mathrm{T}}$ and $\mathrm{H} 23-19$, were isolated from a sea sediment sample that had been collected from Kamogawa beach, Chiba, Japan. Approximately $1 \mathrm{~g}$ of the sample was diluted 10-, 100- and 1000-fold with artificial sea water (Wako Pure Chemical Industries, Osaka, Japan) before $0.2 \mathrm{ml}$ of each dilution was spread on plates of $0.2 \times$ NBRC medium 802 (Polypepton (Wako) $2 \mathrm{~g}$, yeast extract $0.4 \mathrm{~g}, \mathrm{MgSO}_{4} \cdot 7 \mathrm{H}_{2} \mathrm{O} 0.2 \mathrm{~g}$ and agar $15 \mathrm{~g}$ in 1.01 distilled water; pH 7.0) supplemented with $\mathrm{NaCl}\left(30 \mathrm{~g}^{-1}\right)$, cycloheximide $\left(50 \mathrm{mg}^{-1}\right)$ and nalidixic acid $\left(20 \mathrm{mg}^{-1}\right)$. After cultivation at $30^{\circ} \mathrm{C}$ for 1 week and repeated isolation, strains $\mathrm{H} 23-8^{\mathrm{T}}$ and $\mathrm{H} 23-19$ were obtained. As the isolates did not require $\mathrm{NaCl}$ for growth, full-strength $\mathrm{NBRC}$ medium 802 (Polypepton (Wako) $10 \mathrm{~g}$, yeast extract $2 \mathrm{~g}$ and $\mathrm{MgSO}_{4} \cdot 7 \mathrm{H}_{2} \mathrm{O} 1 \mathrm{~g}$ in 1.01 distilled water; agar $15 \mathrm{~g}$, if required; $\mathrm{pH} 7.0$ ) was used as the basal medium for this study. Biomass for chemotaxonomic and molecular systematic studies, except for fatty acid analysis, was obtained by culturing the novel strains in shake flasks of liquid NBRC medium 802 at $28^{\circ} \mathrm{C}$ and 100 r.p.m. for $48 \mathrm{~h}$. Biomass grown on tryptic soy agar for $24 \mathrm{~h}$ at $28^{\circ} \mathrm{C}$ was used for cellular fatty acid analysis. Agromyces terreus KCTC $19216^{\mathrm{T}}$ and Agromyces tropicus NBRC $109073^{\mathrm{T}}$ were used as the reference strains in this study.

\section{Morphological, physiological and biochemical tests}

Colony appearance and pigment production were examined after incubation at $28^{\circ} \mathrm{C}$ for 3 days on agar plate of NBRC medium 802. Morphological features were observed with age (up to 7 days) under a light microscope (model BX-51; Olympus, Tokyo, Japan) and a scanning electron microscope (model JSM6060; JEOL, Tokyo, Japan). The temperature range and optimum temperature 
for growth were determined by incubating the cultures at $5,10,15,20,25,28$, 37,45 and $60^{\circ} \mathrm{C}$ on agar plates of NBRC medium 802 after 5 days of incubation. Growth at 5 and $10^{\circ} \mathrm{C}$ was evaluated after 14 days of incubation. The $\mathrm{pH}$ range and $\mathrm{NaCl}$ tolerance for growth were determined by measuring the turbidity $(610 \mathrm{~nm})$ of $5 \mathrm{ml}$ of the culture medium in test tubes after 1-5 days of incubation at $28^{\circ} \mathrm{C}$. The $\mathrm{pH}$ range and optimum $\mathrm{pH}$ for growth were established by using a liquid NBRC medium 802 adjusted to $\mathrm{pH} 4-11$ in 1.0 $\mathrm{pH}$ unit intervals. Tolerance to $\mathrm{NaCl}$ was tested using a liquid NBRC medium 802 adjusted to $\mathrm{NaCl}$ concentrations of $1,3,5,6,7,8,9,10$ and $15 \%(\mathrm{w} / \mathrm{v})$. Growth under anaerobic and microaerobic conditions was determined using AnaeroPack-Anaero and AnaeroPack-MicroAero (Mitsubishi Gas Chemical, Tokyo, Japan) with anaerobic jars, respectively. Cell motility, Gram staining, oxidase and catalase activities were determined using the methods described previously. ${ }^{11}$ Other physiological and biochemical tests were performed using API ZYM and API Coryne systems (bioMérieux, Lyon, France) according to the manufacturer's instructions.

16S rRNA gene sequence determination and phylogenetic analysis DNA was isolated using PrepMan Ultra Reagent (Applied Biosystems, Foster City, CA, USA) according to the manufacturer's instructions. 16S rRNA gene was amplified by PCR using KOD FX (Toyobo, Osaka, Japan) with the following pair of primers: 9F ( $5^{\prime}$-GAGTTTGATCCTGGCTCAG- $\left.3^{\prime}\right)$ and 1541R $\left(5^{\prime}\right.$-AAGGAGGTGATCCAGCC- $\left.3^{\prime}\right)$. The amplified 16S rRNA gene was subjected to cycle sequencing using a BigDye Terminator v3.1 Cycle Sequencing Kit (Applied Biosystems) with the following primers: 9F, 785F (5'-GGATTAGATACCCTGGTAGTC- $\left.3^{\prime}\right), \quad$ 802R (5'-TACCAGGGTATCTAATCC-3') and 1541R. The products were analyzed using an automated DNA sequencer (model ABI PRISM 3730 Genetic Analyzer; Applied Biosystems). The phylogenetic neighbors were identified and pairwise 16S rRNA gene sequence similarities were calculated using the EzTaxon-e server. ${ }^{12}$ The almost-complete $16 \mathrm{~S}$ rRNA gene sequences (1486 nt) determined in this study were aligned with reference sequences of the genus Agromyces by using the CLUSTAL_X program. ${ }^{13}$ Phylogenetic trees were constructed by the neighbor-joining, maximum-likelihood and maximum-parsimony algorithms ${ }^{14-16}$ using the MEGA 5.0 program. ${ }^{17}$ The resultant tree topologies were evaluated by bootstrap analysis ${ }^{18}$ based on 1000 replicates.

\section{G + C content of DNA and DNA-DNA hybridization}

DNA was obtained using the method of Saito and Miura. ${ }^{19}$ The DNA G + C content was determined by the method of Tamaoka and Komagata ${ }^{20}$ using HPLC (model LC-10A; Shimadzu, Kyoto, Japan). The microplate hybridization method developed by Ezaki et al. ${ }^{21}$ was used to determine DNA-DNA relatedness.

\section{Chemotaxonomic tests}

Amino acids and their isomers in cell-wall hydrolysates and isoprenoid quinones were analyzed as described previously. ${ }^{11}$ The acyl type of muramic acid was determined by using the method of Uchida et al. ${ }^{22}$ The preparation and analysis of cellular fatty acid methyl esters were performed using the protocol of the MIDI Sherlock Microbial Identification System ${ }^{23}$ and GC (model 6890N; Agilent Technologies, Santa Clara, CA, USA) with Sherlock MIDI software (version 4.0) and a TSBA database (version 4.0, MIDI Inc., Newark, DE, USA). Polar lipid analysis was performed as described by Hamada et al. $^{24}$ with the following chromatographic systems: chloroform/methanol/ water (65: 25: 4, by vol.) used in the first direction and chloroform/acetic acid/ methanol/water (80: 18: 12: 5, by vol.) in the second direction.

\section{Nucleotide sequence accession numbers}

The GenBank/EMBL/DDBJ accession numbers for the 16S rRNA gene sequences of strains $\mathrm{H} 23-8^{\mathrm{T}}$ and $\mathrm{H} 23-19$ are $\mathrm{AB} 847104$ and $\mathrm{AB} 847105$, respectively.

\section{RESULTS AND DISCUSSION}

Strains H23-8 ${ }^{\mathrm{T}}$ and H23-19 formed pale yellow, circular, transparent and smooth colonies that were $\sim 1.0 \mathrm{~mm}$ in diameter after 3 days of cultivation. Pigment production was not observed. Both isolates developed branched vegetative hyphae (width $0.4-0.6 \mu \mathrm{m}$ ) in the early phase of growth (Figure 1), but these hyphae subsequently fragmented into rod-like to coccoid fragments. The cells were Gram stain positive, microaerophilic to aerobic, non-motile and nonendospore-forming, catalase positive and oxidase negative. The isolates grew at $10-37^{\circ} \mathrm{C}$ (optimum $28^{\circ} \mathrm{C}$ ) and at $\mathrm{pH} \quad 6.0-10.0$ (optimum $\mathrm{pH}$ 7.0-8.0). The isolates exhibited good growth with $\mathrm{NaCl}$ concentrations of $0-6 \%(\mathrm{w} / \mathrm{v})$ and moderate growth with $7-8 \%$; no growth was observed with 9,10 or $15 \% \mathrm{NaCl}$. The results of other physiological and biochemical analyses are summarized in the species description below.

Phylogenetic analysis, based on 16S rRNA gene sequences, suggested that strains $\mathrm{H} 23-8^{\mathrm{T}}$ and $\mathrm{H} 23-19$ closely related to members of the genus Agromyces. However, both isolates did not form a reliable cluster with any recognized member of the genus Agromyces (Figure 2). The highest similarity values of strains $\mathrm{H} 23-8^{\mathrm{T}}$ and $\mathrm{H} 23-$ 19 were observed with $A$. terreus $(97.30 \%, 97.44 \%)$, followed by A. tropicus $(97.13 \%, 97.23 \%)$, A. salentinus (96.86\%, 96.93\%), A. aurantiacus $(96.79 \%, 96.92 \%)$, A. luteolus $(96.79 \%, 96.92 \%)$ and A. ulmi $(96.78 \%, 96.92 \%)$, respectively. The similarity value between strains $\mathrm{H} 23-8^{\mathrm{T}}$ and $\mathrm{H} 23-19$ was $99.87 \%$. Strains $\mathrm{H} 23-8^{\mathrm{T}}$ and H23-19 exhibited levels of DNA-DNA relatedness of $16 \%$ and $11 \%$ to A. terreus KCTC $19216^{\mathrm{T}}$, and $24 \%$ and $17 \%$ to A. tropicus NBRC $109073^{\mathrm{T}}$, respectively. Meanwhile, the DNA-DNA relatedness value between strains $\mathrm{H} 23-8^{\mathrm{T}}$ and $\mathrm{H} 23-19$ was $85 \%$.

The obtained peptidoglycan samples of strains $\mathrm{H} 23-8^{\mathrm{T}}$ and H23-19 contained alanine (Ala), glutamic acid (Glu), glycine (Gly) and $\mathrm{A}_{2}$ bu at molar ratios of $0.7: 1.0: 1.2: 1.8$ and $0.8: 1.0: 1.2: 1.5$, respectively. Enantiomeric analysis of the peptidoglycan amino acids revealed the presence of D-Ala, D-Glu, Gly and L-A $\mathrm{A}_{2}$ bu. These data suggested that the cell-wall peptidoglycan of both isolates is of the B1 type ${ }^{25}$ and contains mostly L- $\mathrm{A}_{2}$ bu as the diagnostic diamino acid. This result was consistent with those described in the previous report. ${ }^{26}$ The acyl type of muramic acid was $N$-acetyl. The predominant menaquinones of strains $\mathrm{H} 23-8^{\mathrm{T}}$ and $\mathrm{H} 23-19$ were MK-13 (55.5\%, 54.2\%) and MK$12(31.5 \%, 37.4 \%)$; MK-14 (13.0\%, 8.4\%) was present as a minor component. The major cellular fatty acids $(>10 \%)$ of strains $\mathrm{H} 23-8^{\mathrm{T}}$ and $\mathrm{H} 23-19$ were anteiso- $\mathrm{C}_{15: 0}(41.8 \%, 39.6 \%)$, anteiso- $\mathrm{C}_{17: 0}(33.4 \%$,

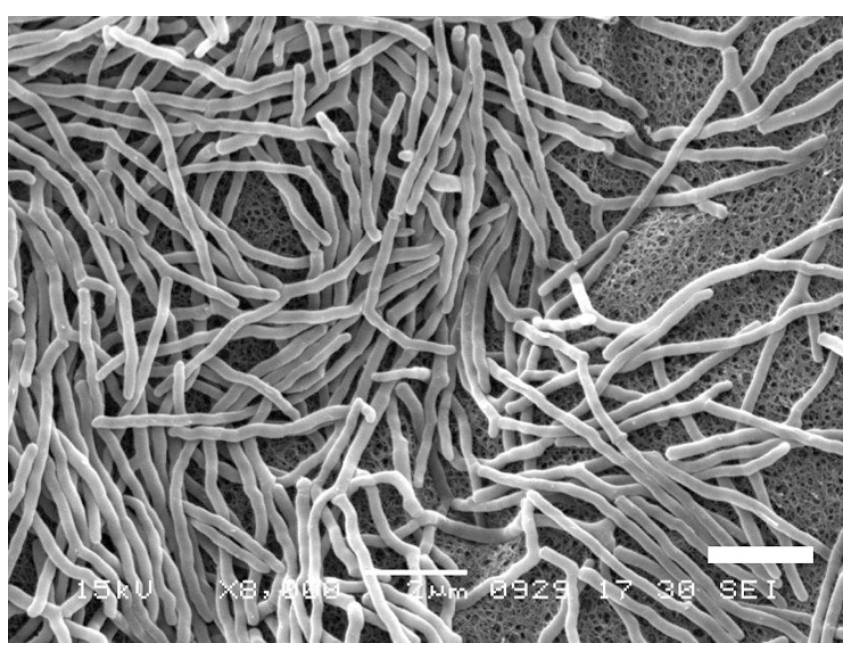

Figure 1 Scanning electron micrograph of strain $\mathrm{H} 23-8^{\top}$ grown on NBRC medium 802 for 1 day at $28^{\circ} \mathrm{C}$. Bar, $2 \mu \mathrm{m}$. 


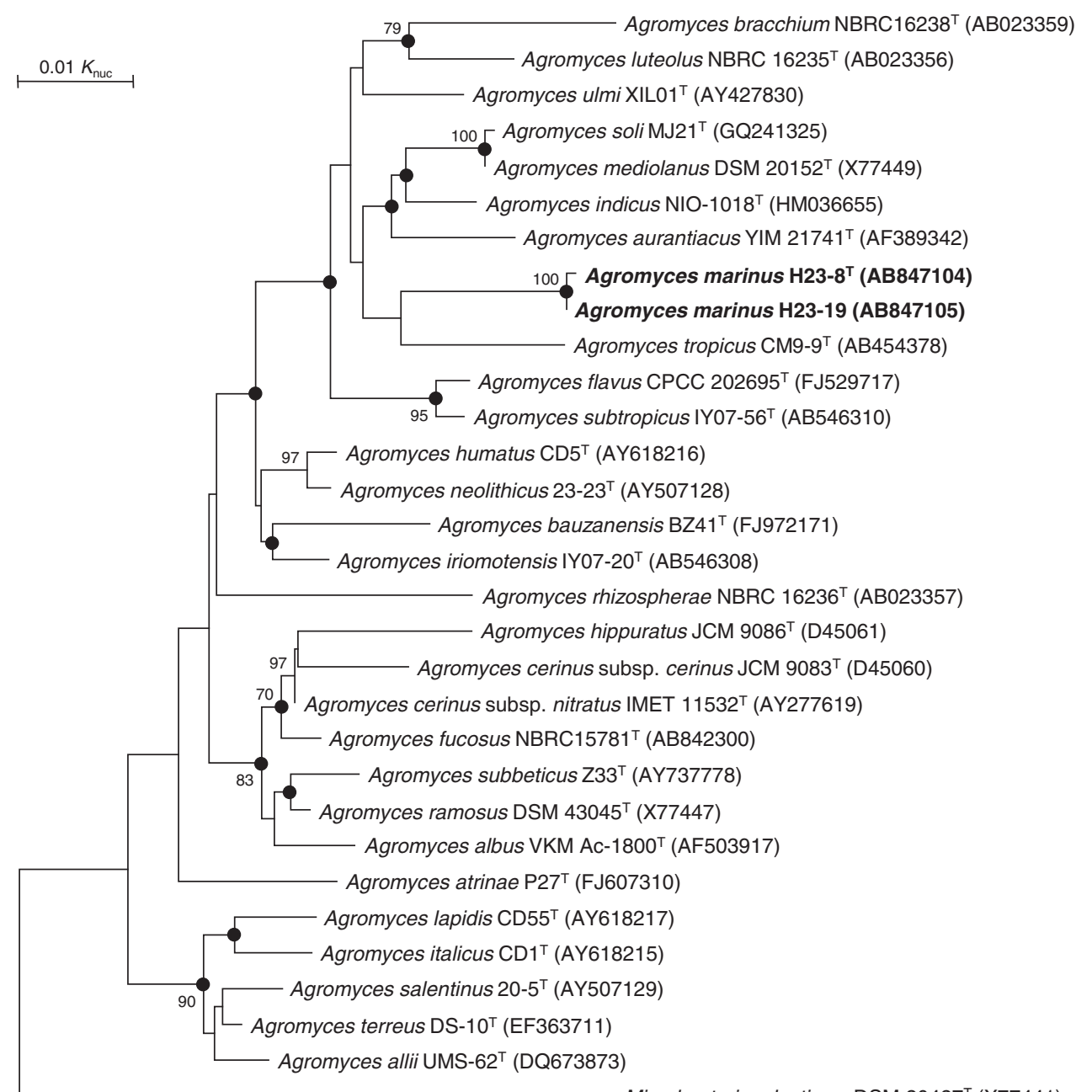

- Microbacterium lacticum DSM 20427 (X77441)

Figure 2 Neighbor-joining phylogenetic tree derived from the 16S rRNA gene sequences of strain H23-8 ${ }^{\top}$ and $\mathrm{H} 23-19$ and the members of the genus Agromyces. The 16S rRNA gene sequence of Microbacterium lacticum DSM 20427 (X77441) was used as the outgroup. The numbers at the branch nodes are bootstrap percentages (from 1000 replicates); only values of $70 \%$ or above are shown. Filled circles indicate that the corresponding nodes were also recovered in the tree generated with the maximum-likelihood and maximum-parsimony algorithms. Bar, $0.01 K_{\text {nuc }}$ substituted per nucleotide position.

Table 1 Cellular fatty acid compositions (\%) of strains $\mathrm{H} 23-8^{\top}$ and H23-19 and related Agromyces species

\begin{tabular}{|c|c|c|c|c|}
\hline Fatty acid & 1 & 2 & 3 & 4 \\
\hline $\mathrm{C}_{16: 0}$ & $\operatorname{tr}$ & - & 1.9 & $\operatorname{tr}$ \\
\hline Iso- $C_{14: 0}$ & tr & $\operatorname{tr}$ & - & - \\
\hline Iso- $C_{15: 0}$ & 3.7 & 4.4 & 16.1 & 7.3 \\
\hline Iso- $C_{16: 0}$ & 18.2 & 15.9 & 10.9 & 15.3 \\
\hline Iso- $C_{17: 0}$ & 1.4 & 1.9 & 9.7 & 2.7 \\
\hline Anteiso- $C_{15: 0}$ & 41.8 & 39.6 & 31.1 & 37.1 \\
\hline Anteiso- $C_{17: 0}$ & 33.4 & 37.5 & 30.3 & 36.8 \\
\hline
\end{tabular}

Strains: 1, Agromyces marinus sp. nov. H23-8'; 2, A. marinus sp. nov. H23-19; 3, Agromyces terreus KCTC 19216 $; 4$, Agromyces tropicus NBRC $109073^{\top}$. All strains are cultivated on tryptic soy agar at $28^{\circ} \mathrm{C}$ for $24 \mathrm{~h}$ and were analyzed in parallel in this study.

Bold type shows the major components ( $>10 \%$ ).

The symbol ' - ' indicates not detected or detected in trace amounts $(<1 \%)$

$37.5 \%)$ and iso- $\mathrm{C}_{16: 0}(18.2 \%, 15.9 \%)$ (Table 1). The polar lipids of both isolates were diphosphatidylglycerol, phosphatidylglycerol and one unidentified glycolipid. The DNA G + C contents of strains H23$8^{\mathrm{T}}$ and $\mathrm{H} 23-19$ were 72.5 and $72.3 \mathrm{~mol} \%$, respectively.
The result of the phylogenetic analysis, based on the $16 \mathrm{~S}$ rRNA gene sequences, suggested that strains $\mathrm{H} 23-8^{\mathrm{T}}$ and $\mathrm{H} 23-19$ belonged to the genus Agromyces, and their chemotaxonomic features also corresponded to those of the genus. Therefore, it is appropriate to regard strains $\mathrm{H} 23-8^{\mathrm{T}}$ and H23-19 as members of the genus Agromyces. The $16 \mathrm{~S}$ rRNA gene sequence similarity between strains $\mathrm{H} 23-8^{\mathrm{T}}$ and $\mathrm{H} 23-$ 19 was $99.87 \%$ and the DNA-DNA relatedness between both strains was $85 \%$. These results indicate that strains $\mathrm{H} 23-8^{\mathrm{T}}$ and $\mathrm{H} 23-19$ belong to same species. Meanwhile, the DNA-DNA relatedness between the isolates and related Agromyces species was low, and the results of the physiological and biochemical tests distinguished strains H23-8 ${ }^{\mathrm{T}}$ and H23-19 from related Agromyces species (Table 2). On the basis of the results of the phylogenetic analysis and DNA-DNA hybridization and their distinctive phenotypic characteristics, it is proposed that strains $\mathrm{H} 23-8^{\mathrm{T}}$ and $\mathrm{H} 23-19$ be classified as a novel species of the genus Agromyces, with the names Agromyces marinus sp. nov. The type strain of $A$. marinus is $\mathrm{H} 23-8^{\mathrm{T}}$.

\section{Description of Agromyces marinus sp. nov}

Agromyces marinus (ma.ri'nus. L. masc. adj. marinus, of the sea, the origin of the sample from which the type strain was isolated). 
Table 2 Differential phenotypic characteristics of strains $\mathrm{H} 23-8^{\top}$ and H23-19 and related Agromyces species

\begin{tabular}{|c|c|c|c|c|}
\hline Characteristic & 1 & 2 & 3 & 4 \\
\hline Growth at $37^{\circ} \mathrm{C}$ & + & + & - & + \\
\hline $\mathrm{pH}$ range for growth & $6-10$ & $6-10$ & $5-10^{a}$ & $6-12^{b}$ \\
\hline \multicolumn{5}{|l|}{$A P I Z Y M$} \\
\hline$N$-Acetyl- $\beta$-glucosaminidase & - & - & + & - \\
\hline Acid phosphatase & - & - & + & w \\
\hline$\beta$-Galactosidase & - & - & + & w \\
\hline$\alpha$-Glucosidase & - & - & + & - \\
\hline$\beta$-Glucosidase & - & - & + & + \\
\hline Trypsin & - & - & + & - \\
\hline \multicolumn{5}{|l|}{ API coryne } \\
\hline Aesculin & - & - & + & + \\
\hline Nitrate reduction & + & + & + & - \\
\hline Glucose & - & - & + & + \\
\hline Sucrose & - & - & + & + \\
\hline DNA G + C content (mol\%) & 72.5 & 72.3 & $71.1^{\mathrm{a}}$ & $72.7^{b}$ \\
\hline
\end{tabular}

Strains: 1, Agromyces marinus sp. nov. $\mathrm{H} 23-8^{\top}$; 2, A. marinus sp. nov. H23-19; 3, Agromyces terreus KCTC 19216 ; 4, Agromyces tropicus NBRC $109073^{\top}$.

The symbol ' + ' indicates positive and '-' negative; ' $w$ ' is weakly positive. Data are from this study unless indicated.

ayoon et al. ${ }^{27}$

bThawai et al.28

Cells are Gram-stain-positive, microaerophilic to aerobic, nonmotile and non-endospore-forming. Young culture produces branched vegetative hyphae (width $0.4-0.6 \mu \mathrm{m}$ ) that subsequently break up into rod-like to coccoid fragments. Colonies are pale yellow, smooth, circular and transparent. Catalase-positive and oxidase-negative. Grows at $10-37^{\circ} \mathrm{C}$ (optimum $28^{\circ} \mathrm{C}$ ) and $\mathrm{pH}$ 6.0-10.0 (optimum $\mathrm{pH} 7.0-8.0)$. Growth occurs with $\mathrm{NaCl}$ concentrations of $0-8 \%(\mathrm{w} / \mathrm{v})$ but not with 9\%. Using the API ZYM system, activity is detected for cystine arylamidase, esterase (C4) (weak), esterase lipase (C8) (weak), leucine arylamidase, naphthol-AS-BI-phosphohydrolase (weak) and valine arylamidase (weak). No activity is detected for $\mathrm{N}$-acetyl$\beta$-glucosaminidase, acid phosphatase, alkaline phosphatase, chymotrypsin, $\alpha$-fucosidase, $\alpha$ - and $\beta$-galactosidases, $\alpha$ - and $\beta$-glucosidases, $\beta$-glucuronidase, lipase (C14), $\alpha$-mannosidase, trypsin and urease. Using the API Coryne system, positive reactions are observed for nitrate reduction, gelatin hydrolysis, pyrazinamidase and fermentation of maltose and D-xylose. Negative reactions are observed for aesculin ( $\beta$-glucosidase), alkaline phosphatase, $\beta$-galactosidase, $\alpha$-glucosidase, $\beta$-glucuronidase, pyrrolidonyl arylamidase and fermentation of glucose, glycogen, lactose, D-mannitol, D-ribose and sucrose. The peptidoglycan contains D-Ala, D-Glu, Gly and L- $\mathrm{A}_{2}$ bu. The predominant menaquinones are MK-13 and MK-12; MK-14 is present as a minor component. The major cellular fatty acids are anteiso- $\mathrm{C}_{17: 0}$, anteiso- $\mathrm{C}_{15: 0}$ and iso- $\mathrm{C}_{16: 0}$. The principal polar lipids are diphosphatidylglycerol, phosphatidylglycerol and one glycolipid.

The type strain H23-8 $8^{\mathrm{T}}\left(=\mathrm{NBRC} 109019^{\mathrm{T}}=\mathrm{DSM} 26151^{\mathrm{T}}\right)$ was isolated from a sea sediment sample from Kamogawa beach, Chiba, Japan. Strain H23-19 (= NBRC 109020), from same sample, is a second strain of the species. The DNA G $+\mathrm{C}$ content of the type strain is $72.5 \mathrm{~mol} \%$.
1 Gledhill, W. E. \& Casida, L. E. Predominant catalase-negative soil bacteria. III. Agromyces, gen. n., microorganisms intermediary to Actinomyces and Nocardia. Appl. Microbiol. 18, 340-349 (1969).

2 Zgurskaya, H. I. et al. Emended description of the genus Agromyces and description of Agromyces cerinus subsp. cerinus sp. nov., subsp. nov., Agromyces cerinus subsp. nitratus sp. nov., subsp. nov., Agromyces fucosus subsp. fucosus sp. nov., subsp. nov., and Agromyces fucosus subsp. hippuratus sp. nov., subsp. nov. Int. J. Syst. Evol. Microbiol. 42, 635-641 (1992).

3 Akimov, V. N. \& Evtushenko, L. I. Genus IV. Agromyces. in Bergey's Manual of Systematic Bacteriology. 2nd edn, Vol. 5 (eds Goodfellow, M. et al.) 862-876 (Springer, New York, 2012).

4 De Maria, S. et al. Interactions between accumulation of trace elements and macronutrients in Salix caprea after inoculation with rhizosphere microorganisms. Chemosphere 84, 1256-1261 (2011).

5 Trifonova, R., Postma, J. \& van Elsas, J. D. Interactions of plant-benefical bacteria with the ascomycete Coniochaeta ligniaria. J. Appl. Microbiol. 106, 1859-1866 (2009).

6 Zakhia, F. et al. Diverse bacteria associated with root nodules of spontaneous legumes in Tunisia and first report for nifH-like gene within the genera Microbacterium and Starkeya. Microb. Ecol. 51, 375-393 (2006).

7 Dastager, S. G. \& Damare, S. Marine actinobacteria showing phosphate-solubilizing efficiency in Chorao Island, Goa, India. Curr. Microbiol. 66, 421-427 (2013).

8 Beleneva, I. A. \& Zhukova, N. V. Bacterial communities of brown and red algae from Peter the Great Bay, the Sea of Japan. Mikrobiologiia 75, 410-419 (2006).

9 Blunt, J. W. et al. Marine natural products. Nat. Prod. Rep. 24, 31-86 (2007).

10 Lam, K. S. Discovery of novel metabolites from marine actinomycetes. Curr. Opin. Microbiol. 9, 245-251 (2006).

11 Hamada, M. et al. Luteimicrobium album sp. nov., a novel actinobacterium isolated from a lichen collected in Japan, and emended description of the genus Luteimicrobium. J. Antibiot. 65, 427-431 (2012).

$12 \mathrm{Kim}, \mathrm{O}$. S. et al. Introducing EzTaxon-e: a prokaryotic 16S rRNA gene sequences database with phylotypes that represent uncultured species. Int. J. Syst. Evol. Microbiol. 62, 716-721 (2012).

13 Thompson, J. D., Gibson, T. J., Plewniak, F., Jeanmougin, F. \& Higgins, D. G. The CLUSTAL_X windows interface: flexible strategies for multiple sequence alignment aided by quality analysis tools. Nucleic Acids Res. 25, 4876-4882 (1997).

14 Saitou, N. \& Nei, M. The neighbor-joining method: a new method for reconstructing phylogenetic trees. Mol. Biol. Evol. 4, 406-425 (1987).

15 Felsenstein, J. Evolutionary trees from DNA sequences: a maximum likelihood approach. J. Mol. Evol. 17, 368-376 (1981).

16 Fitch, W. M. Toward defining the course of evolution: minimum change for a specific tree topology. Syst. Zool. 20, 406-416 (1971).

17 Tamura, K. et al. MEGA5: molecular evolutionary genetics analysis using maximum likelihood, evolutionary distance, and maximum parsimony methods. Mol. Biol. Evol. 28, 2731-2739 (2011).

18 Felsenstein, J. Confidence limits on phylogenies: an approach using the bootstrap. Evolution 39, 738-791 (1985)

19 Saito, H. \& Miura, K. Preparation of transforming deoxyribonucleic acid by phenol treatment. Biochim. Biophys. Acta 72, 619-629 (1963).

20 Tamaoka, J. \& Komagata, K. Determination of DNA base composition by reversedphase high-performance liquid chromatography. FEMS Microbiol. Lett. 25, 125-128 (1984).

21 Ezaki, T., Hashimoto, Y. \& Yabuuchi, E. Fluorometric deoxyribonucleic acid-deoxyribonucleic acid hybridization in microdilution wells as an alternative to membrane filter hybridization in which radioisotopes are used to determine genetic relatedness among bacterial strains. Int. J. Syst. Bacteriol. 39, 224-229 (1989).

22 Uchida, K., Kudo, T., Suzuki, K. \& Nakase, T. A new rapid method of glycolate test by diethyl ether extraction, which is applicable to a small amount of bacterial cells of less than one milligram. J. Gen. Appl. Microbiol. 45, 49-56 (1999).

23 Sasser, M. Identification of bacteria by gas chromatography of cellular fatty acids, MIDI Technical Note 101. MIDI Inc. (Newark, Delaware (1990).

24 Hamada, M. et al. Mobilicoccus pelagius gen. nov., sp. nov and Piscicoccus intestinalis gen.nov., sp. nov., two new members of the family Dermatophilaceae, and reclassification of Dermatophilus chelonae (Masters et al. 1995) as Austwickia chelonae gen. nov., comb. nov. J. Gen. Appl. Microbiol. 56, 427-436 (2010).

25 Schleifer, K. H. \& Kandler, O. Peptidoglycan types of bacterial cell walls and their taxonomic implications. Bacteriol. Rev. 36, 407-477 (1972).

26 Sasaki, J., Chijimatsu, M. \& Suzuki, K. Taxonomic significance of 2,4-diaminobutyric acid isomers in the cell wall peptidoglycan of actinomycetes and reclassification of Clavibacter toxicus as Rathayibacter toxicus comb. nov. Int. J. Syst. Bacteriol. 48, 403-410 (1998).

27 Yoon, J. H., Schumann, P., Kang, S. J., Park, S. \& Oh, T. K. Agromyces terreus sp. nov. isolated from soil. Int. J. Syst. Evol. Microbiol. 58, 1308-1312 (2008).

28 Thawai, C., Tanasupawat, S., Suwanborirux, K. \& Kudo, T. Agromyces tropicus sp. nov., isolated from soil. Int. J. Syst. Evol. Microbiol. 61, 605-609 (2011). 